\title{
MELACAK JAKARTA DARI 1950-AN SAMPAI DENGAN 1970-AN DALAM KARYA SASTRA
}

\section{TRACING JAKARTA FROM THE 1950s TO THE 1970s IN LITERARY WORKS}

\author{
Erli Yetti, Erlis Nur Mujiningsih \\ Badan Pengembangan dan Pembinaan Bahasa \\ Jalan Km 4, Tangkil, Citeureup, Bogor, Jawa Barat \\ Pos-el: yettierli@gmail.com
}

*)Naskah diterima: 23 April 2021; direvisi: 23 April 2021; disetujui: 28 Mei 2021

\begin{abstract}
Abstrak
Artikel ini ditulis dengan tujuan melakukan pelacakan wilayah Jakarta dalam karya Bukan Pasar Malam, Keajaiban di Pasar Senen, Matias Akankari, dan Ali Topan Anak Jalanan. Pelacakan wilayah di dalam karya sastra ini menjadi penting untuk melengkapi pembuatan peta yang dilakukan oleh kartograf. Metode yang digunakan dalam penelitian ini adalah metode kualitatif. Teori yang digunakan adalah sosiologi sastra dan kartografi. Hasil penelitian yang didapatkan adalah wilayah-wilayah yang digambarkan dalam 4 karya sastra yang dibahas pada tahun 1950-an sampai 1960-an adalah wilayah Jakarta Pusat. Wilayah ini digambarkan sebagai sebuah tempat yang padat penduduknya, juga pusat peradaban atau pusat kebudayaan, secara khusus Pasar Senen. Jakarta pada masa itu merupakan kota yang ramai dan sudah penuh dengan debu, tetapi masih dikelilingi oleh dusun dan wilayah persawahan. Pada tahun 1970-an kondisi Jakarta sudah mulai berubah. Kota satelit Kebayoran Baru dikenal sebagai wilayah orang "gedongan". Beberapa tempat wisata juga sudah ada yakni Bina Ria dan Taman Ria Senayan. Namun, ada yang menarik sejak tahun 1950-an sampai 1970-an kehidupan malam di kota Jakarta sudah ramai.
\end{abstract}

Kata kunci: Jakarta, kartografi, Jakarta Pusat, Kebayoran Baru

\begin{abstract}
It aims to track literary works of Bukan Pasar Malam, Keajaiban di Pasar Senen, Matias Akankari, And Ali Topan Anak Jalanan in Jakarta. This tracing is important in order to complete the mapmaking by cartographers. It is qualitative research. The theories used are sociology of literature and cartography. The result reveals that Central Jakarta was the areas described in those four literary works in the 1950s to the 1960s. It was described as a densely populated place, as well as a center of civilization or cultural center, especially Pasar Senen. Jakarta at that time was a busy city and full of dust, but it was still surrounded by villages and rice fields. In the 1970s Jakarta had begun to change. The satellite city of Kebayoran Baru was known as the area of "gedongan" people. There were several tourist attractions, namely Bina Ria and Taman Ria Senayan. There was an interesting fact about the busy night life in Jakarta since the 1950s to the 1970s.
\end{abstract}

Keywords: Jakarta, cartography, Central Jakarta, Kebayoran Baru. 


\section{PENDAHULUAN}

Selama ini perhatian terhadap karya sastra seringkali lebih ditekankan pada halhal yang berkaitan dengan tokoh dan peristiwa yang melingkupinya. Perhatian terhadap setting atau latar tidaklah begitu intens. Latar seolah-olah hanyalah sekadar pendukung saja. Padahal latar memegang peranan yang penting. Di dalam karya drama, misalnya, latar yang konkret biasanya akan berhubungan dengan tokoh dan peristiwa yang konkret. Sebaliknya, latar yang abstrak biasanya akan berkaitan dengan tokoh dan peristiwa yang abstrak (Hasanuddin, 1996: 30). Peran penting latar ini kemudian memunculkan satu pendekatan baru dalam kajian sastra yaitu kajian yang berkaitan dengan peta sastra atau dikenal juga dengan kajian kartografi. Peta sastra atau dikenal juga sebagai geografi sastra dalam hal ini dimaknai sebagai pelacakan wilayah dan ruang yang digunakan dan ada di dalam sebuah karya sastra.

Pelacakan wilayah dan ruang di dalam karya sastra ini dilakukan untuk melengkapi pembuatan peta sebagaimana yang sudah dilakukan oleh para katograf. Sebagaimana disampaikan oleh Piatti (2009: 179) bahwa dalam kartografi modern pemetaan dilakukan untuk memberikan gambaran terhadap semua fenomena dan tampaknya dari dalam karya sastra yang salah satu sifatnya adalah memotret keadaan diharapkan dapat memberikan prespektif yang berbeda. Walaupun diakui bahwa ranah fiksi memiliki aturan yang berbeda dari keadaan yang nyata. Namun, dari dalam karya sastra tersebut pengarang memberikan emosi atas pandangannya dalam melihat kondisi di sekelilingnya. Hal inilah yang tidak didapatkan apabila seorang pembuat peta hanya melihat dan memetakan suatu wilayah secara normal. Irisan yang didapatkan dari geografi sastra adalah melihat ruang dan waktu dalam dunia fiksi dan ruang dan waktu dalam dunia nyata. Dalam hal ini ahli sastra hanyalah akan berperan menyiapkan bahan, sementara pekerjaan untuk membuat peta akan diserahkan kepada kartograf atau pembuat peta. Penelitian semacam ini sebagaimana disebutkan oleh Piatti (2009:180) merupakan penelitian interdispliner. Oleh sebab itu, penelitian yang dikemas dalam bentuk artikel dilakukan dengan tujuan menyiapkan bahan bagi kerja berikutnya yang akan dilaksanakan oleh kartograf.

Sehubungan dengan hal itu, secara khas artikel ini akan melakukan pelacakan wilayah Jakarta yang ada dalam karya sastra dengan membaca beberapa karya sastra yang diterbitkan dalam kurun waktu berbeda. Karya pertama adalah Bukan Pasar Malam karya Pramoedya Ananta Toer dengan latar waktu tahun 1950-an atau sehabis perang kemerdekaan, Keajaiban di Pasar Senen sebuah kumpulan cerpen karya Misbach Jusa Biran yang juga menampilkan Jakarta pada tahun 1950an, cerpen "Matias Akankari" karya Gerson Poyk yang menampilkan Jakarta pada tahun 1960-an, dan karya Teguh Esha Ali Topan Anak Jalanan yang menampilkan Jakarta tahun 1970-an.

Karya-karya tersebut dipilih dengan beberapa pertimbangan. Salah satunya adalah keterwakilan dalam menampilkan kondisi Jakarta dalam segi waktu. Hal ini dimaksudkan untuk melihat perkembangan kota Jakarta dari waktu ke waktu. Kota Jakarta dipilih sebagai titik tumpu penelitian ini dengan pertimbangan bahwa kota ini merupakan ibukota negara yang menjadi tempat tinggal berbagai suku bangsa yang ada di Indonesia. Kota ini juga menjadi tempat persinggahan warga negara dari berbagai negara di dunia. Kota ini pun menjadi salah satu wajah Indonesia di mata dunia yang sudah hadir jauh sebelum kemerdekaan. Belanda dan Jepang juga menjadikan kota ini sebagai pusat pemerintahan. 
Sebagaimana kita ketahui kata Jakarta berasal dari peristiwa kemenangan Fatahillah pada tanggal 22 Juni 1957. Tanggal tersebut kemudian diperingati sebagai hari lahir kota Jakarta. Pada tanggal tersebut, nama Sunda Kelapa berubah menjadi Jayakarta dan selanjutnya berubah menjadi Jakarta (Sudjarwoko, 2010: 9). Jakarta sebagai sebuah ibukota negara tentunya memiliki keistimewaan tersendiri. Jakarta merupakan sebuah wilayah yang diberi otonomi dalam lingkup provinsi. Hal ini dilakukan oleh pemerintah karena Jakarta memiliki tanggung jawab yang besar dan tantangan yang kompleks. Beberapa masalah yang dihadapi Jakarta, antara lain, urbanisasi, keamanan, transportasi, lingkungan, pengelolaan kawasan, dan masalah sosial kemasyarakatan lainnya. Jakarta terbagi dalam 5 wilayah kota administrasi dan 1 kabupaten administrasi, dengan batas wilayah sebelah selatan adalah Kota Depok, Jawa Barat, sebelah timur adalah Kota Bekasi, Jawa Barat, sebelah barat adalah Kota Tangerang, Banten, sebelah utara adalah Laut Jawa. Luas provinsi ini adalah $661,52 \mathrm{~km}^{2}$ daratan dan $6.977,5 \mathrm{~km}^{2}$ lautan. Lima Wilayah kota administrasi dan satu kabupaten administrasi itu adalah Jakarta Selatan dengan jumlah penduduk 1.894 .362 jiwa, Jakarta Timur dengan jumlah penduduk 2.625.737 jiwa, Jakarta Pusat dengan jumlah penduduk 923.299 jiwa, Jakarta Barat dengan jumlah penduduk 1.635.227 jiwa, Jakarta Utara dan Kabupaten administrasi Kepulauan Seribu dengan jumlah penduduk 1.443.964 jiwa. Jumlah penduduk ini adalah kondisi pada tahun 2010 (Sudjarwoko, 2010: 10).

Sebagaimana sudah disampaikan sebelumnya bahwa Jakarta sebagai ibukota negara memiliki permasalahan yang rumit. Selain itu, sebagai sebuah ibukota negara dan sekaligus wajah negara ini tentunya Jakarta dapat dikatakan harus membangun dirinya untuk makin baik secara lebih cepat dibandingkan dengan wilayah-wilayah lainnya. Bagaimana Jakarta mengatasi persoalan-persoalan yang dihadapi dan seperti apa perkembangan kota ini dari tahun ke tahun dipotret dalam berbagai karya sastra yang terbit di Indonesia. Potret itu - dalam bentuk karya sastra - tentunya tidak akan serupa benar dengan aslinya karena di dalamnya sudah masuk pendapat dan pikiran pengarangnya. Namun, tetap fungsi karya sastra sebagai "juru potret" ini menjadi cukup penting untuk melengkapi atau bahkan menjadi bahan bagi ahli-ahli lain dalam mewujudkan pekerjaannya. Salah satunya sebagaimana sudah disebutkan sebelumnya hasil penelitian ini mungkin akan menjadi bahan yang berharga untuk para kartograf dalam menyusun peta karena penelitian ini dilakukan dengan tujuan melacak perkembangan wilayahwilayah yang ada di Jakarta melalui karya sastra.

\section{LANDASAN TEORI}

Teori yang digunakan dalam penelitian ini adalah sosiologi sastra. Salah satu hal yang menjadi perhatian sosiologi sastra adalah sastra sebagai cermin masyarakat. Sastra memang berhubungan dengan masyarakatnya. Seorang pengarang memang menuliskan hal-hal yang berkaitan dengan masyarakatnya. Namun, pengertian "cermin" dalam konteks ini harus dipahami dengan bijak karena boleh jadi sebuah karya sastra yang berusaha menampilkan keadaan masyarakat secermat-cermatnya tidak dapat dipercaya sebagai cermin masyarakat. Sebaliknya, karya yang sama sekali tidak dimaksudkan untuk menggambarkan masyarakat masih dapat digunakan sebagai bahan untuk mengetahui keadaan masyarakatnya. Pandangan sosial pengarang harus diperhitungkan dalam hal ini (Damono, 1979: 4). Di sisi yang lain, Plekanov pada awal abad 
XX menyampaikan bahwa kritik sastra Soviet menandaskan kesaksian sosial yang diungkapkan karya sastra (Escarpit, 2008: 78). Teori ini digunakan dalam analisis untuk melacak kota Jakarta dalam beberapa karya sastra untuk membantu mendeskripsikan latar sosial dalam karya sastra yang dianalisis. Pelacakan terhadap latar sosial ini diperlukan untuk menemukan gambaran kondisi Jakarta pada karya-karya tersebut yang nantinya dapat dimanfaatkan oleh kartograf dalam pembuatan peta.

Selanjutnya, teori yang digunakan adalah kartografi. Secara khas dalam hubungannya dengan karya sastra, hal yang menjadi titik tumpu adalah komunikasi kartografi. Komunikasi kartografi dapat diterapkan pada peta/gambar. Peta topografi memberikan gambaran dari suatu tempat dan unsurunsur yang ada di muka bumi. Meskipun seseorang belum mengenal suatu daerah, tetapi dengan adanya komunikasi kartografi diharapkan orang tersebut dapat membaca dan mengerti peta daerah itu. Dengan adanya komunikasi kartografi seseorang yang membaca peta diharapkan dapat mengenal bentang darat daerah tersebut dengan baik. Gambaran suatu tempat sebagaimana dikehendaki dalam komunikasi kartografi tidak hanya terbatas dalam kondisi fisik wilayah tersebut, tetapi juga kondisi sosial kemasyarakatannya. Dari sisi inilah karya sastra dapat dikatakan bermanfaat untuk membantu kartograf dalam mewujudkan komunikasi kartografi tersebut (Piatti, 2009: 182)

Dalam rangka pelacakan wilayah tersebut hal-hal yang akan dianalisis dari dalam karya sastra tersebut adalah setting tempat aksi atau peristiwa berlangsung, zone of setting atau lingkungan (kota, desa, wilayah), projected space atau lokasi yang diingat, diimpikan oleh tokoh termasuk di dalamnya tempat yang lain yang tidak termasuk dalam dua kategori sebelumnya, dan yang terakhir adalah rute atau perjalanan/pergerakan para tokoh (Piatti, 2009: 185). Hal-hal inilah yang akan dilacak dalam beberapa karya yang dianalisis. Dari keempat aspek itu diharapkan akan didapatkan gambaran yang utuh sebuah lokasi tertentu, dalam hal ini adalah kota Jakarta.

\section{METODE PENELITIAN}

Metode yang digunakan dalam penelitian ini adalah metode kualitatif. Metode kualitatif adalah metode yang mengharuskan penelitinya untuk mencari makna, pemahaman, pengertian, verstehen tentang suatu fenomena, kejadian, maupuan kehidupan manusia dengan terlibat langsung dan/atau tidak langsung dalam setting yang diteliti, kontekstual, dan menyeluruh (Yusuf, 2014: 328). Metode ini akan digunakan untuk memahami dan mencari makna dalam karya novel Bukan Pasar Malam, kumpulan cerpen Keajaiban di Pasar Senen, cerpen "Matias Akankari", dan novel Ali Topan Anak Jalanan. Hal ini perlu dilakukan dalam rangka mencari jejak kota Jakarta yang terdapat dalam karya-karya tersebut.

Objek penelitian yang digunakan adalah novel Bukan Pasar Malam karya Pramoedya Ananta Toer, kumpulan cerpen Keajaiban di Pasar Senen karya Misbach Jusa Biran, Cerpen "Matias Akankari" karya Gerson Poyk, dan Ali Topan Anak Jalanan karya Teguh Esha. Novel Bukan Pasar Malam dan kumpulan cerpen Keajaiban di Pasar Senen dipilih sebagai objek penelitian karena karya ini memberikan gambaran kota Jakarta pada tahun 1950-an dengan nuansa yang berbeda. Cerpen "Matias Akankari" dipilih untuk memberikan gambaran Jakarta pada tahun 1960-an. Ali Topan Anak Jalanan dipilih untuk memberikan gambaran Jakarta pada tahun 1970-an.

Langkah-langkah penelitian ini adalah sebagai berikut. Pertama, penentuan dan klasifikasi data, yaitu mengumpulkan data 
sesuai dengan rumusan masalah tentang bagaimana potret Jakarta dari tahun 1950an sampai dengan 1970-an dilihat dari segi kondisi wilayah dan kondisi sosial kemasyarakatannya. Data primer berupa lima karya sastra yang berupa novel dan cerpen sebagaimana sudah disebutkan sebelumnya. Data sekunder berupa berbagai bahasan mengenai kota Jakarta dan juga mengenai kelima karya sastra tersebut.

Kedua, analisis data yaitu aplikasi teori sosiologi sastra pada lima karya sastra. Data yang sudah terkumpul dikelompokkan sesuai dengan teori yang sudah ditentukan dan berbagai bahasan tentang kota Jakarta digunakan untuk mendukung pelacakan wilayah dalam karya sastra. Analisis dilakukan dengan memperhatikan dan mencatat setting, zone of setting, projected space, dan rute dalam setiap karya. Metode yang digunakan adalah kajian pustaka dengan analisis isi. Metode kajian pustaka dilakukan dengan cara membaca, menandai, dan menganalisis teks-teks dalam karya yang memberikan gambaran tentang Jakarta dalam beberapa waktu yang berbeda.

\section{HASIL DAN PEMBAHASAN}

Untuk mendapatkan gambaran kota Jakarta dari waktu ke waktu mulai tahun 1950-an sampai dengan tahun 1970-an secara lengkap dilakukan pelacakan dalam novel Bukan Pasar Malam, kumpulan cerpen Keajaiban di Pasar Senen, cerpen "Matias Akankari", dan novel Ali Topan Anak Jalanan. Berdasarkan urutan waktu akan dianalisis mulai dari karya yang menggambarkan kota Jakarta tahun 1950-an. Wilayah mana saja yang digambarkan dalam karya tersebut dan seperti apa gambaran wilayah tersebut.

\section{Jakarta tahun 1950-an}

Ada dua karya sastra yang dianalisis untuk pelacakan kondisi Jakarta tahun 1950an. Pertama adalah novel Bukan Pasar Malam karya Pramoedya Ananta Toer. Karya novel ini terbit pertama kali tahun 1951 oleh Penerbit Balai Pustaka. Selanjutnya, novel ini terbit dalam berbagai bahasa, antara lain bahasa Melayu, Jerman, Prancis, Belanda, dan juga dalam edisi Singapura. Karya ini juga dicetak ulang oleh berbagai penerbit. Selain Balai Pustaka, penerbit Lentera juga menerbitkan ulang karya ini dengan beberapa kali cetakan. Hal ini menunjukkan bahwa karya Pramoedya ini diminati oleh khalayak dari berbagai kalangan. Novel ini juga dapat dikatakan merupakan karya yang melegenda seperti halnya karya-karya Pramoedya lainnya. Teeuw (1980: 82) menyampaikan bahwa karya ini memesona dan mengagumkan walaupun disampaikan dengan cara yang amat bersahaja. Suasana muram dan tak terdamaikan serta zaman yang tak berbelaskasihan menandai karya Pramoedya ini. Rosidi (1986: 101) juga menyebutkan karya ini sebagai salah satu karya Pramoedya walaupun, karya ini tidak dibicarakannya secara khusus. Ada satu skripsi yang ditulis oleh Priyatno (2017: 11). Skripsi ini berjudul Konteks Sosial dan Id eologi Proletar Tokoh U tam a dalam Novel Bukan Pasar Malam Karya Pramoedya Ananta Toer. Pada pembicaraan mengenai konteks sosial disebutkan oleh Priyatno (2017: ix) bahwa yang melatari karya ini adalah situasi Indonesia ketika revolusi tahun 1945-1950. Disebutkan oleh Priyatno (2017: 31) bahwa Jakarta merupakan simbol kemajuan dan kemegahan yang berbanding terbalik dengan kota Blora yang disebutnya sebagai simbol kemiskinan dan menandai belum meratanya kemakmuran. Hal yang serupa juga disampaikan oleh Halimah (2009: 33) bahwa di dalam karya novel ini tergambarkan ketimpangan sosial antara warga miskin di kota kecil dengan warga kaya di kota-kota besar.

Novel Bukan Pasar Malam memiliki lingkungan setting di dua kota, yaitu Jakarta dan 
Blora. Untuk Jakarta setting yang disebutkan adalah sebuah jalanan kecil di depan istana. Kondisi istana kepresidenan digambarkan oleh penulisnya terang benderang karena waktu penggambaran adalah malam hari. Disebutkan bahwa istana presiden memakai daya listrik sampai lima kilowatt. Penggambaran kondisi istana yang dilakukan oleh Pramoedya ini tampaknya dengan maksud untuk mengontraskan kondisi kehidupan warga biasa dan warga istimewa (dalam hal ini presiden). Istana kepresidenan di Jakarta terletak di Jalan Merdeka Utara sekarang berdekatan dengan Taman Monumen Nasional di atas tanah seluas 6,8 hektar dan ketinggian kurang lebih 5 meter dari permukaan laut. Istana kepresidenan terdiri dari dua bangunan istana, yaitu Istana Merdeka yang menghadap Monas (saat ini), dan Istana Negara yang menghadap Sungai Ciliwung di Jalan Veteran (Punyaubay, 2014). Pada novel Bukan Pasar Malam tidak disinggung adanya sungai yang dimunculkan adalah adanya sebuah jalan kecil. Oleh sebab itu, tampaknya yang dimaksudkan di dalam karya ini adalah Istana Merdeka. Dari sini didapatkan gambaran bahwa di depan istana presiden pada masa itu masih ada sebuah jalan kecil yang dapat dilalui oleh masyarakat secara bebas.

Tempat lainnya yang disebutkan di dalam karya ini adalah Stasiun Gambir, Stasiun Jatinegara, dan juga wilayah Klender. Gambaran dua stasiun ini juga wilayah Klender yang berada di pinggiran rel kereta api menampakkan bekas-bekas perang.

Kemudian Klender pun nampaklah dari jendela kereta itu. Bangkai-bangkai pantserwagen, brencarrier, truk, bergelimpangan di ladang-ladang dan di pinggir jalan raya-senjata Inggris yang dilumpuhkan oleh barisan pemuda, dan juga dilumpuhkan oleh ketuaannya sendiri (Toer, 2013: 13).
Dalam karya novel Juga digambarkan kondisi daerah Cakung yang ada di sepanjang rel kereta, juga Kranji, Tambun, Cikarang, dan Lemah Abang. Tempat-tempat itu tidak digambarkan secara terperinci oleh pengarangnya karena memang hanya dilalui saja dan digambarkan melalui kaca jendela sebuah kereta api. Yang digambarkan oleh pengarangnya mengenai wilayah-wilayah tersebut adalah sawah-sawah, rumpun bambu, pohon-pohon, dan kebun karet. Wilayah-wilayah itu disebutkan oleh pengarangnya sebagai kota-kota kecil. Ada juga disebut sebagai dusun. Hal ini menandai bahwa kota Jakarta pada masa itu masih di kelilingi oleh wilayah pedesaan yang hijau. Dari gambaran ini juga dapat disampaikan bahwa jalur kereta api penumpang pada masa itu dimulai dari Stasiun Gambir kemudian Stasiun Jatinegara dilanjutkan terus ke arah Timur, Cakung, Kranji, Tambun, Cikarang, dan Lemah Abang.

Pada novel ini juga digambarkan kondisi kota Jakarta ketika sang tokoh berkeliling untuk mencari hutang ke temantemannya guna keperluan perjalanannya menjenguk ayahnya yang sakit di Blora. Kota Jakarta digambarkan dipenuhi dengan mobil dan debu, tetapi masih ada kendaraan yang ditarik kuda, ada sepeda, juga ada becak. Namun, kesan mengenai kota Jakarta ini yang ada di benak sang tokoh adalah Jakarta juga kota-kota besar lainnya identik dengan mobil dan bajingan. Beberapa kali hal ini disebutkan oleh sang tokoh ketika bertemu dengan teman serta kerabatnya di Blora. Kondisi kota Jakarta pada karya novel ini memang tidak terlalu terperinci karena sang tokoh kemudian bergerak ke kota Blora dan lebih banyak beraktivitas di kota Blora. Dengan demikian, dapat disampaikan di sini bahwa Jakarta yang digambarkan di sini adalah Jakarta di sekitar istana presiden dan Jakarta dilihat dari dalam kereta mulai dari Stasiun Gambir sampai di wilayah sekitar 
Cakung. Jakarta dalam pandangan pengarangnya bukanlah sebuah kota yang menyenangkan. Jakarta sudah dipenuhi dengan debu.

Wilayah yang dipotret oleh penulis Bukan Pasar Malam berbeda dengan wilayah yang dipotret oleh penulis kumpulan cerpen Keajaiban di Pasar Senen. Dari judulnya saja segera dapat dimaknai bahwa latar cerita dalam kumpulan cerpen ini adalah Pasar Senen. Pasar Senen merupakan sebuah pasar yang dibentuk pertama kali oleh seorang pengacara bernama Justinus Vinck sekitar tahun 1733. Pasar ini dibentuk untuk menggeser pusat transaksi ke luar stad (kota) Batavia agar terjadi pertemuan pedagangpedagang Tionghoa dan Arab dari Batavia dengan pedagang-pedagang pribumi dari wilayah pedesaan. Pasar ini terbentuk di sisi jalan poros baru antara benteng (fort) Noordwijk di Batavia melalui kampungkampung utama di sisi timur sungai Ciliwung sampai benteng (fort) Pajajaran di hulu sungai Ciliwung (Akhir Matua Harahap, 2019:59). Pasar Senen yang digambarkan dalam kumpulan cerpen ini adalah kondisi wilayah tersebut pada tahun 1950-an. Pasar Senen pada masa ini merupakan sebuah tempat berkumpulnya seniman sehingga muncul sebutan Seniman Senen. Sebagaimana disebutkan Ardan (1971: 7) pada pengantar buku ini bahwa ada pihak-pihak dan orang-orang yang berusaha untuk menciptakan kembali wilayah tersebut di tempat yang lain. Disebutkan Usmar Ismail mengusahakan agar lantai II Sarinah dijadikan semacam "Senen" juga Ali Sadikin bermaksud menjadikan Taman Ismail Marzuki serupa dengan "Senen" bagi seniman.

Penggambaran wilayah yang ada di dalam kumpulan cerpen ini wilayah di sekitar bioskop Grand. Sebagaimana disebutkan dalam cerpen "Roby Alias Ibnu Saad dan Nandi", "Pengabdi Seni Drama" bahwa di sekitar tikungan Medan Senen sebelah bioskop Grand ada sebuah kedai kopi yang bermerek "Cau An". Di kedai inilah para tokoh dalam cerpen ini berkumpul. Tempat lainnya yang digambarkan adalah restoran yang terletak di belakang bioskop Grand, di pengkolan oplet ke Jatinegara sebagaimana muncul dalam cerpen "Kopi Kecil dan Asap Rokok". Di dalam cerpen ini disebut juga "ada banyak tempat: sambil berdiri di tikungan Grand, di warung Mak Itam, di tukang kue putu". Pada cerpen "Kalau Bung Seniman Jangan Tinggal di Kampung" disebutkan nama warung penjual kue putu yaitu Cirebon. Di sebelah warung tersebut terdapat teng bensin. Keberadaan tukang kue putu dan teng bensin ini juga disebutkan dalam cerpen "Keajaiban di Pasar Senen". Di pengkolan senen tersebut juga ada warung si Kecil, warung Cina yang menjual buah dingin. Jadi, dapat dikatakan di sini bahwa ada dua orang Cina yang berjualan di pengkolan senen, yaitu kedai kopi "Cau An" dan warung si Kecil. Di pengkolan senen tersebut juga ada tukang majalah yang di dekatnya ada warung kopi si Toyib yang terdapat dalam cerpen "Dunia Bobrok". Dengan demikian, terdapat dua warung kopi yakni warung kopi "Cau An" dan warung kopi si Toyib.

Di dalam cerpen "Dunia Bobrok" ini juga disebutkan bahwa sang tokoh berjalanjalan menyusuri toko-toko di deretan Tay San Kongsi dan juga menyebutkan Kedai Ismail Merapi yang berada di seberang Tay San Kongsi. Dalam catatan sejarah Tay San Kongsi ini kemudian menjadi toko buku Gunung Agung. Sebagaimana disebutkan Fadrik Aziz Firdausi (2019: 2) Wei Tay awalnya berjualan buah yang kemudian beralih ke berjualan rokok ketengan di jalanan sekitar Glodok dan Pasar Senen. Dari berjualan rokok inilah ia kemudian berkenalan dengan Lie Tay San dan The Kie Hoat yang 
kemudian mengajaknya membuat kongsi dagang. Maka berdirilah Tay San Kongsie pada tahun 1945. Selepas kemerdekaan Tay San Kongsie membuka toko buku impor dan majalah yang sebelumnya berjualan rokok dan bir karena ternyata bisnis toko buku ini lebih menguntungkan dibandingkan dengan rokok dan bir. Tahun 1953 Tay San mundur tinggal Wie Tay dan Kie Hoat yang kemudian membentuk Firma Gunung Agung.

Keberadaan kedai Ismail Merapi sebagai tempat berkumpulnya seniman secara lebih jelas disampaikan pada cerpen "Keajaiban di Pasar Senen" yang sebelumnya sudah disebutkan dalam cerpen "Dunia Bobrok".

Kedai nasi Padang "Ismail Merapi" juga merupakan tempat parkir para seniman dan teman-teman seniman. Ke sana saya melangkah, tetapi di sini juga sepi. Maksud saya tidak ada seniman. Tamu-tamu cuma beberapa pedagang. Saya turut duduk di situ, segan pergi-pergi lagi. Di sini saya bisa duduk tenang. Pegawai-pegawai kedai ini tak menganggu saya, menanyakan mau minum atau makan apa, mereka sudah kenal bahwa saya sering datang dengan seniman-seniman ke situ, pasti hanya akan dudukduduk saja. Ah, iseng-iseng mendengarkan pedagang berbincang. Sejak saya main-main dengan seniman, perhatian saya rada kurang pada pedagang. Padahal mereka bertumpuk-tumpuk di daerah ini (Biran, 1971: 84).

Apa yang disampaikan pengarang dalam cerpen "Keajaiban di Pasar Senen" terlihat bahwa wilayah tersebut yakni kawasan Senen merupakan tempat berkumpulnya seniman di samping itu juga menjadi tempat berkumpulnya para pedagang. Seniman yang berkumpul di tempat itu berasal dari berbagai wilayah dan juga berbagai zaman. Sebagaimana disebutkan dalam cerpen "The Glory is Over" disampaikan bah salah satu tokohnya yang berbicara atau bercerita adalah seorang seniman tua yang terkenal pada masa Opera Stambul Bangsawan. Kelompok sandiwara ini populer sebelum perang.

Seniman yang berkumpul juga merupakan seniman yang berasal dari berbagai jenis. Ada pelukis dan ada penulis. Ada juga yang bukan seniman tetapi ingin menjadi seniman atau yang berpura-pura ingin menjadi seniman. Kegiatan yang mereka lakukan adalah "mengobrol" dan bisanya disertai dengan minum kopi dan merokok. Mereka melakukannya sepanjang malam atau juga di siang hari. Dengan demikian, dapat disampaikan bahwa kawasan Pasar Senen ini menjadi istimewa karena yang awalnya sebagai sebuah pasar hanya diperuntukkan bagi bertemunya para pedagang yakni pedagang Cina dan Arab dengan pedagang pribumi, tetapi kemudian di tahun 1950-an tempat ini pun menjadi tempat berkumpulnya seniman yang kemudian terkenal menjadi boleh dikatakan sebagai komunitas seniman senen.

Dari dua karya yang dianalisis ini didapatkan simpulan bahwa Jakarta pada tahun 1950-an sudah menjadi sebuah kawasan yang ramai. Sebuah kota yang penuh debu dari ban-ban mobil sebagaimana digambarkan dalam novel Bukan Pasar Malam dan tempat berkumpulnya seniman yang sekaligus berkembangnya seniman. Di kawasan Pasar Seniman dapat secara bebas "ngobrol", "nongkrong-nongkrong", dan "jalan-jalan" tanpa ada yang menegur. Pemilik kedai pun sudah memaklumi keberadaan para seniman tersebut. Seniman yang berkumpul tersebut berasal dari berbagai tempat dan berbagai masa sehingga dapat dikatakan bahwa Jakarta dengan Pasar Senennya sudah menjadi salah satu "pusat" 
untuk seniman pada tahun 1950-an, selain pusat pemerintahan karena di dalam novel Bukan Pasar Malam juga disebutkan keberadaan istana presiden di Jakarta.

\section{Jakarta tahun 1960-an}

Apabila di tahun 1950-an kawasan Jakarta yang diperlihatkan oleh dua karya sastra adalah kawasan di sekitar istana presiden dan kawasan Senen, pada tahun 1960-an kawasan yang diperlihatkan dalam karya cerpen "Matias Akankari" juga masih kawasan yang berada tidak terlalu jauh dari dua kawasan tersebut, yakni kawasan Lapangan Banteng dan juga ada menyinggung kawasan Senen. Cerpen "Matias Akankari" merupakan salah satu cerpen karya Gerson Poyk yang diterbitkan pertama kali di kumpulan cerpen dengan judul yang sama pada tahun 1972 di Balai Pustaka. Buku kumpulan cerpen ini terbit ulang pada tahun 1975. Pada kumpulan cerpen ini dimuat enam cerpen, antara lain "Reuni", "Matias Akankari", "Anatomi Perjalanan", "Penjual Kerbau", "Dusun yang Sangat Melarat", dan "Krawang-Bekasi". Matias Akankari juga dimuat di kumpulan Laut Biru Langit Biru (1977) yang disusun oleh HB Jassin. Dalam cerpen ini dikisahkan seorang bernama Matias seorang laki-laki Irian yang dibawa seorang parasutis ke Jakarta. Gambaran kota Jakarta yang ada dalam karya cerpen ini adalah gambaran dari seseorang yang sebelumnya hidup di hutan rimba Irian Jaya. Kondisi kota Jakarta dibandingkannya dengan kondisi alam Irian Jaya. Oleh sebab itu, disebutkan di dalam cerpen ini bahwa Jakarta adalah sebuah kota yang disebutnya "hutan rimba manusia, hutan lampu, hutan roda becak dan mobil, hutan bunyi, hutan hura hara yang tidak setenang dan seramah rimba raya". Wilayah dan tempat-tempat yang disinggahi oleh tokoh dan disebutkan dalam karya cerpen ini adalah Senen. Disebutkan di dalam cerpen ini bahwa di Senen terdapat bioskop, tampaknya kalau dihubungkan dengan kumpulan cerpen Keajaiban di Pasar Senen bioskop tersebut adalah bioskop Grand. Matias juga digambarkan berjalan kaki dan disebutkan bahwa apa yang dilakukan oleh Matias adalah hal yang istimewa karena "orang-orang di Jakarta biasa hidup di atas roda". Apabila dikaitkan dengan novel Bukan Pasar Malam memang di Jakarta ini sudah penuh dengan mobil. Tokoh ini kemudian juga bertemu dengan gereja, tetapi tidak disebutkan gereja itu letaknya di mana. Hanya kemudian tokoh ini yang bertemu dengan seorang pemuda sarjana pengangguran pergi menuju Lapangan Banteng dan tidur di bawah patung pembebasan Irian Barat. Disebutkan bahwa di Lapangan Banteng di bawah patung Pembebasan Irian Barat kondisi lantainya bagus karena disebutkan bahwa jenis ubinnya adalah ubin mahal. Patung pembebasan Irian Barat dibangun tepat di tengah-tengah Lapangan Banteng. Patung ini dibangun untu;k memperingati masuknya Irian Barat dalam pangkuan (Lubis, 2018: 213). Latar cerpen ini adalah waktu peristiwa pembebasan Irian Barat sebagaimana disebutkan Korwa (2013:3) bahwa pada 19 Desember 1961 Presiden Soekarno memerintahkan dibentuknya Tri Komando Rakyat (Trikora) yang merupakan sebuah bentuk serangan militer terbatas dari Indonesia terhadap Belanda di Irian Barat. Hal ini terus menerus terjadi sampai muncul perjanjian New York pada tanggal 15 Agustus 1962 yang menjadikan Belanda harus menyerahkan Irian Barat ke Indonesia. Jadi, dapat dikatakan peristiwa-peristiwa di dalam cerpen ini terjadi di sekitar tahun 1960-an atau sesudah tahun 1963. Disebutkan oleh (Pattiasina, 2014: 55) bahwa Bung Karno pada tahun 1962 berprakasa mendirikan patung-patung di daerah-daerah umum di Jakarta, seperti di depan Hotel Indonesia 
(patung Selamat Datang), di Lapangan Banteng (patung Pembebasan Irian Barat), dan di Cawang (patung Dirgantara). Patung Pembebasan Irian Barat didirikan pada tahun 1963. Dengan demikian dapat disampaikan bahwa latar cerita ini adalah setelah 1962 atau setelah patung Pembebasan Irian Barat selesai dibangun.

Dari Lapangan Banteng sang tokoh berjalan ke suatu tempat yang banyak gelandangannya. Hanya tidak disebutkan tempatnya dimana. Matias kemudian melanjutkan perjalanannya ke Jalan Thamrin. Dia sampai di depan hotel Indonesia. Yang akhirnya membawa Matias ke sebuah tempat hiburan malam. Hotel Indonesia merupakan bangunan bertingkat tinggi pertama di Jakarta. Hotel ini dibangun dalam rangka Asian Games. Hotel Indonesia dibangun untuk menampung tamu-tamu penting dan para offisial dari kontingenkontingen peserta Asian Games (Lubis, 2018: 215). Oleh sebab itu, di dalam cerpen "Matias Akankari" disebutkan bahwa Matias saat di dekat Hotel Indonesia melihat orang seperti dia yang ternyata adalah Negro Amerika yang kemungkinan besar merupakan bagian dari kontingen Asian Games tersebut. Sebagaimana disebutkan di dalam Lubis (2018: 215) bahwa pada saat Hotel Indonesia pertama kali beroperasi banyak orang yang mengaguminya. Tampaknya hal ini juga terjadi pada tokoh Matias yang memang datang dari Irian.

Dari cerpen ini didapatkan gambaran bahwa kota Jakarta pada masa sekitar tahun 1960-an atau tepatnya setelah 1963 merupakan sebuah kota yang sibuk dan penduduknya juga tidak ramah. Orang-orangnya juga hidup di atas roda. Wilayah-wilayah yang digambarkan di dalam cerpen ini dapat dikatakan wilayah tengah kota yakni Senen, Lapangan Banteng, dan Hotel Indonesia. Apa yang tergambarkan dalam cerpen ini merupakan gambaran yang diperoleh dari warga di luar Jakarta, yakni Papua atau pada cerpen ini disebutkan sebagai laki-laki Irian.

\section{Jakarta tahun 70-an}

Karya yang ditulis Teguh Esha ini sebagaimana disampaikan di awal novel ini terjadi pada tahun 1977. Kota Jakarta yang digambarkan di dalam karya ini adalah kota Jakarta yang pada masa itu dipimpin oleh Ali Sadikin. Novel ini mengisahkan seorang anak muda bernama Ali Topan. Anak muda ini masih sekolah di SMA 1 Bulungan. Disebutkan di dalam karya novel ini sebelumnya SMA Bulungan ini satu sekolah hanya ada yang masuk pagi dan masuk sore. Ketika Gelanggang Remaja Jakarta Selatan dibangun SMA ini dibagi dua. SMA Bulungan pagi menjadi SMA I Bulungan yang terletak di Jalan Mahakam dan SMA Bulungan sore menjadi SMA 2 Bulungan yang terletak di Jalan Bulungan. Membaca cerita ini memang seperti kita berada di tengahtengah kota Jakarta. Gambaran kondisi kota Jakarta, secara khusus, wilayah Kebayoran Baru dengan sangat nyata disampaikan oleh penulisnya.

Beberapa tempat yang digambarkan di dalam karya novel ini adalah wilayah Blok M. Pada karya ini di halaman awal pengarang memberikan gambaran tentang wilayah ini. Digambarkan dalam karya novel ini bahwa

Blok M merupakan sebuah blok perumahan dan pertokoan seluas tigakilometer persegi. Sebelah utaranya dibatasi lapangan Markas Besar Kepolisian atau Mabak, sebelah timur dibatasi Jalan Iskandarsyah Raya, sebelah selatan dibatasi Jalan Melawai Raya, dan sebelah baratnya dibatasi Jalan Sisingamangaraja. Kebayoran Baru terdiri dari beberapa blok, dari A sampai S. Penduduknya umumnya pekerja dan pedagang kelas menengah 
dari luar Jakarta, yang berjumlah sekitar 400.000 orang (Esha, 1977: 7).

Sebagaimana disebutkan oleh Lubis (2018: 91) bahwa wilayah Kebayoran Baru dibangun sebagai kota satelit untuk Jakarta. Pembangunan berlangsung sampai akhir 1950-an. Daerah ini dipilih karena jaraknya dekat dengan Jakarta. Pembangunan wilayah kota satelit Kebayoran Baru diperuntukkan 100.000 penduduk, terutama bagi karyawan dan keluarganya. Memang dapat dikatakan bahwa wilayah Kebayoran Baru merupakan wilayah yang baru dibuka di Jakarta, tetapi sebagaimana disampaikan dalam novel Ali Topan Anak Jalanan pada tahun 1970-an wilayah ini sudah berkembang cukup ramai sebagaimana disebutkan di dalam novel tersebut yang sebelumnya diancangkan hanya untuk jumlah penduduk sekitar 100.000 orang pada tahun 1970 -an sudah mencapai sekitar 400.000 orang. Hal ini menandai perkembangan wilayah Jakarta juga perkembangan penduduknya. Disebutkan oleh Lubis (2018: 93) pembangunan Kebayoran Baru mengikuti konsep Menteng.

Jejak kota Jakarta yang terdapat di dalam karya novel Teguh Esha adalah jejak kota Jakarta pada tahun 1970 -an pada masa pemerintahan Ali Sadikin. Kondisi kota Jakarta pada masa itu sudah dipenuhi oleh bus kota, helicak, mobil-mobil mewah seperti Mercedes dan juga disebutkan mobil Toyota Corolla. Disebutkan juga bahwa Pasar Melawai merupakan pusat wilayah Blok M. Kawasan lain yang juga digambarkan dalam karya novel ini adalah Pasar Mayestik. Kawasan ini disebutkan dipenuhi oleh orang Minang. Juga disampaikan di karya ini sudah adanya Jembatan Semanggi dan Bunderan Senayan. Disebutkan juga bahwa rumah anak-anak muda yang menjadi tokoh dalam karya novel ini ada di daerah Cipete dan Radio Dalam.

Hal yang juga dibicarakan di dalam novel ini persoalan gedongan. Disampaikan bahwa orang Kebayoran ini adalah orang gedongan. Hal ini sejalan dengan apa yang disampaikan Lubis (2018:64-65) disebutkan bahwa orang gedongan ada di wilayah Menteng yang berasal dari orang Indonesia kelas menengah ke atas yang menggantikan dan menempati rumah-rumah orang Belanda. Gedongan ini juga ada di Kebayoran Baru. Wilayah yang sebelumnya diperuntukkan kalangan menengah ke bawah secara bertahap berubah ditempati golongan menengah ke atas. Selain itu, latar waktu karya novel tahun 1970-an menyebutkan bahwa Belanda sudah pergi dan era tahun 1970-an adalah era Amerika.

Wilayah lain yang digambarkan dalam karya novel ini adalah Pantai Bina Ria. Sebagaimana disebutkan oleh Lubis (2018: 343) bahwa Bina Ria merupakan salah satu tempat rekreasi yang dibangun di jaman awal Orba. Taman Ria Ancol dibangun di bekas rawa-rawa Ancol di pantai Teluk Jakarta yang kemudian dikenal dengan nama Bina Ria yang di malam hari dikenal sebagai tempat kencan. Di dalam novel ini pantai Bina Ria menjadi tempat menghilangkan kekesalan hati sang tokoh dan kondisi pantai ini sepi karena dia datang di siang hari. Tempat hiburan lainnya yakni Taman Ria Senayan. Tempat wisata ini sesuai dengan namanya memang berbentuk sebuah taman yang dipenuhi bunga dan juga ada sebuah danau yang disebut dengan Danau Angsa Hitam. Suasana di taman tersebut asri dan hijau. Tokoh Ali Topan dan Anna Karenina berkencan di taman tersebut.

Pada karya ini tidak disinggung tentang tempat-tempat hiburan malam di Jakarta karena mungkin karya ini ditujukan untuk pembaca remaja. Ada beberapa tempat seperti puncak disebutkan sebagai tempat 'mesum', tempat kencan tokoh ayah, tetapi itu dari sudut pandang remaja, juga salon sebagai tempat bertemunya Tante Girang dan laki-laki mudanya. Ini merupakan 
gambaran kehidupan Jakarta untuk masyarakat kalangan menengah ke atas atau disebutkan sebagai orang "gedongan". Hal serupa juga digambarkan dalam cerpen "Matias Akankari". Jakarta merupakan tempat berkumpulnya masyarakat kalangan atas dan juga masyarakat kalangan bawah (gelandangan dan lainnya). Perbedaan antara kaya dan miskin tampak jelas dalam karya sastra yang dibahas mewarnai kondisi Jakarta. Namun, di Jakarta juga terukir kisah-kisah orang-orang sukses sebagaimana kisah pendiri Gunung Agung yang nama tokonya menjadi latar dalam cerpen "Dunia Bobrok" dalam kumpulan cerpen Keajaiban di Pasar Senen.

\section{PENUTUP}

Sebagaimana disampaikan di awal bahwa analisis terhadap 4 karya sastra untuk melihat jejak kota Jakarta dalam karya-karya tersebut dilakukan dengan memperhatikan 4 hal yakni setting, zone of setting, projected space, dan route. Analisis yang dilakukan selain melihat kondisi wilayah juga memperhatikan kondisi sosial budaya dengan memperhatikan kurun waktu. Jejak kota Jakarta dalam empat karya tersebut dilihat mulai dari kurun waktu tahun 1950-an sampai dengan tahun 1970-an.

Dari hasil analisis didapat beberapa hal. Setting yang dimanfaatkan oleh pengarang dalam menggambarkan gerak para tokohnya tahun 1950 -an adalah tempat-tempat umum yang memang benar-benar menonjol, yakni jalan kecil di depan istana presiden serta beberapa stasiun kereta mulai dari stasiun Gambir sampai stasiun Cakung dalam novel Bukan Pasar Malam dan Pasar Senen dalam kumpulan cerpen Keajaiban di Pasar Senen. Dua tempat tersebut mewakili kelompok masyarakat kelas bawah dalam hal ini pegawai rendahan dalam Bukan Pasar Malam dan seniman dalam Keajaiban di Pasar Senen. Dengan demikian, zone of settingnya adalah wilayah sekitar Jakarta Pusat atau Jakarta di wilayah tengah.

Wilayah di pusat Jakarta ini dalam tahun 1950-an digambarkan sebagai sebuah wilayah yang ramai. Pasar Senen disebutkan sebagai tempat berkumpulnya seniman. Mereka berkumpul mulai dari sore sampai malam, bahkan malam wilayah itu hidup. Jadi, dapat dikatakan bahwa kehidupan malam di kota Jakarta hidup sudah ada pada tahun 1950-an. Disebutkan juga bahwa Jakarta sudah penuh dengan debu, yakni debu dari mobil, becak, sepeda, dan juga masih ada delman. Sudut pandang yang digunakan untuk menggambarkan kondisi wilayah Jakarta di tengah itu adalah sudut pandang masyarakat kelas bawah. Oleh sebab itu, projected space yang dibayangkan oleh tokoh dalam Bukan Pasar Malam adalah wilayah yang berada di luar jangkauan masyarakat kelas bawah, yakni istana presiden itu sendiri. Sang tokoh dalam Bukan Pasar Malam tidak berada di dalam istana presiden, tetapi dia berada di depan istana presiden di sebuah jalan kecil yang memang merupakan tempat bagi masyarakat kelas bawah. Bayangan tentang istana presiden diwujudkan dengan gambaran mengenai pemakaian lampu di istana tersebut. Kondisi istana presiden yang terang benderang membawa imajinasi sang tokoh untuk menggambarkan kehidupan mewah yang ada di istana presiden yang mewakili kondisi masyarakat kelas atas atau disebutkan sebagai presiden dan para pejabat.

Untuk rute yang dimunculkan dalam dua karya ini yang terlihat melakukan perjalanan adalah di karya Bukan Pasar Malam. Rute yang dilaluinya adalah dari Stasiun Gambir kemudian ke stasiun-stasiun yang mengarah ke Semarang. Dari rute tersebut didapatkan gambaran bahwa kota Jakarta masih dilingkungi oleh dusun-dusun dan wilayah-wilayah yang masih hijau. Wilayah Cakung saja masih disebutkan sebagai 
sebuah dusun. Pada tahun 1950-an ini juga gambaran bekas-bekas perang masih tampak.

Tidak berbeda jauh dengan tahun 1950an, tahun 1960-an setting yang digunakan pengarang untuk menggambarkan peristiwa yang dialami tokoh masih bergerak di sekitar wilayah Jakarta Pusat atau Jakarta yang di tengah-tengah. Setting yang ada dalam karya cerpen "Matias Akankari" adalah Patung Pembebasan Irian Barat di Lapangan Banteng. Kondisi Jakarta yang digambarkan dalam karya ini pada tahun 1960-an juga memunculkan gambaran kemewahan. Patung Irian Barat digambarkan memiliki lantai yang mewah atau ubin yang mahal. Juga disebutkan kondisi jalan Thamrin yang dipenuhi dengan gedunggedung bertingkat. Gambaran kota Jakarta yang ada dalam cerpen ini diwakili oleh tokoh yang hidup di hutan rimba raya Papua. Tidak berbeda dengan gambaran tahun 1950-an zone of setting karya ini juga masih di wilayah Jakarta Pusat. Gambaran kehidupan malam juga muncul dalam cerpen ini yang dideskripsikan mirip dengan tarian di Papua. Projectes space dalam karya ini adalah wilayah Papua. Sementara itu, rute yang dilalui tokohnya adalah masih di wilayah Jakarta Pusat.

Kalau karya-karya yang memberikan jejak Jakarta tahun 1950-an dan 1960-an di wilayah Jakarta Pusat atau di sekitaran Pasar Senen, Jalan Thamrin, Gambir, Istana Presiden, dan Hotel Indonesia. Karya Ali Topan Anak Jalanan yang memberikan gambaran Jakarta tahun 1970-an bergeser ke wilayah Jakarta Selatan, yakni wilayah Kebayoran Baru. Gambaran bahwa Jakarta, terutama wilayah Kebayoran Baru, merupakan wilayah yang dihuni oleh masyarakat kelas atas muncul dalam karya novel ini. Kebayoran Baru memang sejak tahun 1950an dibangun sebagai kota satelit untuk menampung karyawan dan pekerja. Namun, kemudian wilayah ini berkembang menjadi wilayah yang dihuni oleh masyarakat kelas atas atau di dalam karya ini disebut sebagai orang "gedongan". Karya Ashadi Siregar ini memang secara detail mengambarkan wilayah Kebayoran Baru atau secara khusus Blok M. Hal ini dapat dimaknai bahwa keramaian kota Jakarta pada tahun 1970-an sudah bergeser ke Selatan dan tidak hanya di Pusat saja. Zone of setting-nya bergerak Dari wilayah Jakarta Pusat ke wilayah Jakarta Selatan. Dalam karya ini projected space-nya tidak ada. Rute yang dilalui oleh tokoh-tokohnya dari Jakarta Selatan ke Jalan Sudirman sampai ke Pantai Bina Ria.

Apa yang sudah disampaikan di atas dapat disimpulkan bahwa jejak Jakarta yang ada dalam empat karya sastra ini memberikan gambaran bahwa Jakarta pada tahun 1950-an sampai 1970-an merupakan sebuah kota yang dihuni oleh masyarakat golongan atas atau disebut juga sebagai orang gedongan. Namun, juga ada kehidupan masyarakat kelas bawah. Baik masyarakat kelas atas maupun kelas bawah tidak mengalami kesulitan hidup di Jakarta. Kondisi Jakarta, terutama di wilayah Jakarta Pusat sudah ramai dengan mobil, sepeda, delman, dan kendaraan lainnya sehingga disebutkan bahwa kehidupan di Jakarta adalah kehidupan di atas roda. Yang menarik juga adalah bahwa di tiga karya yang menggambarkan kehidupan Jakarta tahun 1950-an dan 1960-an dideskripsikan juga kehidupan malam. Begitu pula karya yang menggambarkan Jakarta tahun 1970-an dimunculkan kehidupan kalangan atas yang penuh dengan perselingkuhan, yang pada masa itu disebut sebagai om senang dan tante girang.

\section{DAFTAR PUSTAKA}

Biran, Misbach Yusa. 1971. Keajaiban di Pasar Senen. Jakarta: Pustaka Jaya. 
Damono, Sapardi Djoko. 1979. Sosiologi Sastra Sebuah Pengantar Ringkas. Jakarta: Pusat Pembinaan dan Pengembangan Bahasa, Departemen Pendidikan dan Kebudayaan.

Escarpit, Robert. 2008. Sosiologi Sastra. Diterjemahakan oleh Ida Sundari Husen dari Sociologie de La Litterature (1958). Jakarta: Yayasan Obor.

Esha, Teguh. 2000. Ali Topan Anak Jalanan. Jakarta:PT Visi Gagas Komunika.

Firdausi, Fadrik Aziz. 2019. “Sejarah Toko Buku Gunung Agung Bermula dari Haji Masagung" dalam today.line.me/id/v2/ article/2rPOyX. Diunduh tanggal 3 Maret 2021.

Halimah. 2009. “Konteks, Fungsi, dan Nilai Sosial Novel Bukan Pasar Malam Karya Pramoedya Ananta Toer sebagai Model Pembelajaran Kajian Prosa Fiksi di Jurusan Pendidikan Bahasa dan Sastra Indonesia, FPBS, UPI Bandung". Laporan Penelitian Pembinaan, Program Pendidikan Bahasa dan Sastra Indonesia, Jurusan Pendidikan Bahasa dan Sastra Indonesia, Fakultas Bahasa dan Seni, Universitas Pendidikan Indonesia.

Harahap, Akhir Matua. 2019. “Sejarah Jakarta (47):Pasar Senen, Pasar Sness, Pasar Lama Weltevreden; Cornelis Chastelein, Vinck, Mossel, Parra, Deandels" dalam poestahadepok. blogspot.com/2019/05/sejarah-jakarta-47pasar-senen.html. Diunduh tanggal 3 Maret 2021.

Korwa, Rycho. 2013. “Proses Integrasi Irian Barat ke dalam NKRI" dalam Jurnal Politico, Volume 2, Nomor 1, Januari 2013. Halaman 1-9. Manado: Universitas Sam Ratulangi.

Lubis, Firman. 2018. Jakarta 1950-1970. Jakarta: Masup.

Pattiasina, Dianthinus Louisa. 2014 “Kajian Estetika dan Realisme Sosialis Tiga Patung Monumen (Patung Selamat
Datang, Pembebasan Irian Barat, dan Dirgantara) Era Soekarno di Jakarta" dalam Jurnal Ilmiah Widya. Volume 2, Nomor 1, Maret-April 2014. Halaman 53-61. Jakarta:Lembaga Ilmu Pengetahuan Indonesia.

Piatti, Barbara, Hans Rudolf Bar, AnneKathin Reuschel, Lorenz Hurni, and William Cartwright. 2009. “Mapping Literature: Towards a Geographic of Fiction" dal am Carthography and Art. William Cartwright, Georg Gartner, Antje Lehn (Editor). Springer, Berlin, Heidellberg.

Poyk, Gerson. 1975. Matias Akankari. Jakarta: Balai Pustaka.

Priyatno, Vicentius Gitiyarko. 2017. “Konteks Sosial dan Ideologi Proletar Tokoh Utama dalam Novel Bukan Pasar Malam Karya Pramoedya Ananta Toer". Skripsi pada Universitas Santa Dharma, Yogyakarta.

Punyaubay. 2014. "Istana Kepresidenan Indonesia" dalam https://www.kaskus. co.id/thread/540335d660e24bcb0a8b4570/ istana-kepresidenan-indonesia/. Diunduh tanggal 3 Maret 2021.

Rosidi, Ajip. 1986. Ikhtisar Sejarah Sastra Indonesia. Bandung: Binacipta.

Sudjarwoko. 2010. “Kontribusi Pajak Daerah dan Retribusi Daerah terhadap Pendapatan Asli Daerah dan Anggaran Pendapatan dan Belanja Daerah Provinsi DKI Jakarta". Tesis pada Univeritas Indonesia, Jakarta.

Teeuw, A. 1980. Sastra Baru Indonesia. Nusa Indah: Ende. Flores.

Toer, Pramoedya Ananta. 2013. Bukan Pasar Malam. Jakarta: Lentera Dipantara.

WS, Hasanuddin. 2009. Drama: Karya dalam Dua Dimensi:Kajian, Teori, Sejarah, dan Analisis. Bandung: Angkasa. 